(C) INSTITUTE OF LINGUISTICS - ADAM MICKIEWICZ UNIVERSITY

AL. NiEPOdLEgŁoŚCI 4, 60-874, POZNAŃ - Poland

\title{
Identyfikacja gatunku mowy pochwały w oparciu o strategię reaktywnego gatunku mowy (SRGM)
}

\section{The identification of "Praise" speech genre based on the Reactive Speech Genre Strategy (RSGS)}

\author{
Anna Wartecka \\ UNIWERSYTET IM. ADAMA MICKIEWICZA \\ AL. NIEPODLEGŁOŚCI 4, 61-874 POZNAŃ \\ annamaceamu.edu.pl
}

\begin{abstract}
The main purpose of this article is to explain the procedure of identifying the utterances of praise using the Reactive Speech Genre Strategy (RSGS). The RSGS is one of the steps of a wider strategy dedicated to identification of "Praise" speech genre. In the article are described 5 stages of RSGS, which include considerations over: the initiative nature of "Praise" speech genre; the role of the reactive nature of "Gratitude" speech genre in identifying the "Praise" speech genre; the analysis of selected speech genres associated with "Praise" and "Gratitude". The linguistic corpus consists of selected utterances of positive assessment taken from the Polish version of a television talent show "Mam talent!".
\end{abstract}

\section{WSTEPP}

Celem artykułu jest opis procedury wyłaniania wypowiedzi chwalaccych z korpusu językowego przy pomocy strategii reaktywnego gatunku mowy (dalej: SRGM). SRGM jest drugim etapem (tzw. „sito 2.”) identyfikacji pochwał, a jej skuteczność jako gatunkowego narzędzia identyfikacyjnego uzależniona jest od przeprowadzenia etapu pierwszego (tzw. „sito 1.” lub „etap sytuacji komunikacyjnej”)1. Na materiał źródłowy będący polem 
zastosowania SRGM² składają się transkrybowane dialogi uczestników³ z jurorami ${ }^{4}$, które mają miejsce $\mathrm{w} 61$ odcinkach eliminacyjnych 9 pierwszych edycji programu telewizyjnego „Mam talent!”, przy czym: 1) dialogi te mają miejsce $\mathrm{w}$ czasie przeznaczonym na ocenę jurorską zaprezentowanego występu oraz (jednocześnie) 2) po dialogach następuje jednogłośna decyzja jurorów o promocji uczestnika do następnego etapu programu (materiał źródłowy został na etapie poprzedzającym SRGM dobrany tak, aby właściwa dialogom sytuacja komunikacyjna sprzyjała wystąpieniu pochwał).

SRGM składa się z następujących kolejno po sobie etapów:

1) stwierdzenia inicjatywnego charakteru gatunku mowy pochwały;

2)ustalenia, jakie gatunki mowy są reaktywne względem gatunku mowy pochwaty;

3) ustalenia, który z gatunków mowy reaktywnych względem gatunku mowy pochwały jest a) na tyle schematyczny, na ile jest to wystarczające do jego jednoznacznej identyfikacji oraz b) na tyle popularny, aby liczba zidentyfikowanych przy jego pomocy wypowiedzi chwalących była wystarczająca do utworzenia reprezentatywnego zbioru pochwał (korpusu pochwal);

4)dokonania identyfikacji w materiale źródłowym wypowiedzi realizujących wybrany reaktywny względem pochwały gatunek mowy (w oparciu o stwierdzony typowy dla niego schemat) i wyszczególnieniu tym samym w tymże materiale wypowiedzi, które antycypują wypowiedzi wybranego gatunku reaktywnego;

5)identyfikacji wśród (wymienionych w poprzednim punkcie) wyszczególnionych wypowiedzi antycypujących tych wypowiedzi, które są inicjatywne względem gatunku podziękowania, lecz nie mogą zostać uznane za pochwałę [i eliminacji ich $\mathrm{z}$ pozyskanego $\mathrm{w}$ rezultacie przeprowadzenia etapu 4. korpusu (tzw. „korpusu potencjalnych pochwal")].

Opisowi powyższych etapów poświęca się poniższą część artykułu.

\section{SRGM - ETAP I}

Inicjatywny charakter gatunku mowy pochwały stwierdza m.in. Małgorzata Marcjanik [która zauważa, że akty dodatniego wartościowania partnera mogą być zarówno inicjatywne, jak i reaktywne - te ostatnie mogą być wynikiem np. prowokacji grzecznościowej lub mogą pełnić funkcję perswazyjną (Marcjanik 2000: 117)] i Beata Drabik [według badaczki użycie pochwały może pociągać za sobą kolejny gatunek mowy (Drabik 2004: 88), a zatem ma ona charakter inicjatywny].

\footnotetext{
$2 \mathrm{~W}$ analizie za pomocą SRGM nie uwzględnia się wypowiedzi, jeśli następująca po nich jednomyślna decyzja jurorów o promocji uczestnika do następnego etapu programu jest podjęta dla żartu (wypowiedzi te mają w przeważającej mierze charakter ironiczny). W analizie pominięto również wypowiedzi, stanowiące komentarz do niektórych występów, których emisja nie miała charakteru ciągłego. 3 Pojęcie „Uczestnik” oznacza w tym miejscu zarówno pojedynczą osobę, jak i tzw. uczestnika zbiorowego (np. duet, zespół, grupę itd.), a także osobę towarzyszącą uczestnikowi.

4 Transkrybowano ponadto wypowiedzi prowadzących program, które pojawiają się w nielicznych dialogach (nie stanowią one przedmiotu zainteresowania na żadnym z ww. etapów identyfikacji pochwał).
} 


\section{Anna Wartecka: Identyfikacja gatunku mowy pochwaty w oparciu o strategię reaktywnego gatunku mowy (SRGM)}

\section{SRGM - ETAP II}

Wśród gatunków reaktywnych względem gatunku mowy pochwały wymienia się: podziękowanie (Marcjanik 2000: 132, Drabik 2004: 88-89); pytanie mówiące o chęci upewnienia się przez adresata, czy nadawca rzeczywiście tak sądzi, jak ujął to $\mathrm{w}$ akcie chwalenia5 (Marcjanik 2000: 133); polemikę z pozytywną opinią partnera (Marcjanik 2000:134, Drabik 2004: 89-90); żart [jako formę grzecznego zdystansowania się od nadawcy pochwały (Marcjanik 2000: 136)]; potwierdzenie oceny zawartej w akcie chwalenia (Marcjanik 2000: 136, Drabik 2004: 91-92); (wzajemną) pochwałę (Marcjanik 2000: 137, Drabik 2004: 92); informację dotyczącą wartościowanego obiektu (Marcjanik 2000: 137, Drabik 2004: 91). Gatunki te mogą współwystępować w obrębie jednej wypowiedzi (Marcjanik 2000: 138, Drabik 2004:92)6. Zdarzają się sytuacje, w których pochwała jest przemilczana, bez zakłócenia przebiegu interakcji (Marcjanik 2000: 137).

\section{SRGM - ETAP III}

Według B. Drabik oraz M. Marcjanik najczęstszą reakcją na pochwałę jest podziękowanie (Drabik 2004: 88, Marcjanik 2000: 132). Jest to jednocześnie gatunek mowy, który (jeśli występuje w swojej najpopularniejszej postaci)7 cechuje wysoki stopień schematyczności [najpopularniejsze w języku polskim formuły podziękowań (przynależące zarówno do formalnego, jak i familiarnego rejestru języka) to: dziękuję, dzięki, dziękujemy, dzięks (Cyluk 2012: 17-18)]. Wysoka schematyczność najczęściej występujących form podziękowania oraz powszechność jego występowania po wypowiedziach chwalących jest czynnikiem decydującym dla wyboru tego gatunku jako gatunku reaktywnego względem pochwały, który posłuży przy zastosowaniu SRGM do jej identyfikacji.

\section{IV.SRGM - ETAP IV}

Identyfikacja w materiale źródłowym wypowiedzi realizujących gatunek podziękowania odbywa się w oparciu o poszukiwanie wśród wypowiedzi uczestników tych wypowiedzi, które zbudowane są wyłącznie z samodzielnie występujących formuł dziękuję, dzięki, dziękujemy, dzięks, przy czym samodzielność ta oznacza, że wyrazy dziękuję, dzięki, dziękujemy, dzięks są jedynymi składowymi wypowiedzi dziękczynnej lub też współwystępują z:

\footnotetext{
5 M. Marcjanik nazywa pochwałę „aktem dodatniego wartościowania partnera” (Marcjanik 200o: 115-138) lub „aprobatą” (Marcjanik 200o: $115)$.

6 M. Marcjanik, która nie posługuje się w cytowanej pracy naukowej terminem „gatunek mowy” (omawiane wypowiedzi nazywane są przez badaczkę „aktami mowy”) opisuje to zjawisko za pomocą następujących słów: „przedstawione powyżej rodzaje replik mogą być łączone [...] w obrębie jednej kwestii dialogu" (Marcjanik 2000: 138).

7 Wypowiedzi będące realizacją gatunku mowy podziękowania mogą przyjmować rozmaite formy - są to zarówno formy explicite, których centrum stanowi czasownik performatywny dziękować, jak i formy pośrednie (pozbawione stałych form i dekodowane przez odbiorców jako podziękowanie na podstawie konkretnej sytuacji komunikacyjnej).
} 
1) elementami językowymi określającymi adresata podziękowania (np. zaimkiem wam w wypowiedzi dziękuję wam //8);

2) przysłówkami, przymiotnikami, wyrażeniami przysłówkowymi, wyrażeniami przymiotnikowymi, wzmocnieniami np. w postaci partykuły (np. wyrażeniem przysłówkowym $z$ całego serca $\mathrm{w}$ wypowiedzi dziękujemy z całego serca //, przymiotnikiem wielkie w wypowiedzi dzięki wielkie //, przysłówkiem bardzo oraz wzmocnieniem $\mathrm{w}$ postaci partykuły naprawdę $\mathrm{w}$ wypowiedzi dziękuję bardzo / naprawdę //);

3) elementami leksykalnymi służącymi wyrażeniu ekspresji (np. wykrzyknikiem ojej w wypowiedzi ojej / dziękuję bardzo //);

4) uzasadnieniem, którego sens da się wyrazić za pomocą form dziękuję za/dziękuję ponieważ (uzasadnienie tego rodzaju pojawia się np. w wypowiedzi dziękuję / jestem bardzo dumny że styszę to od pani //).

W reaktywnych wypowiedziach dziękczynnych wybranych w celu realizacji SRGM dopuszczalne są także powtórzenia oraz współwystępowanie elementów określonych w powyższych czterech punktach. Z analizy wyłącza się te reaktywne wypowiedzi dziękczynne, w których $\mathrm{z}$ samodzielnymi formułami dziękuję, dzięki, dziękujemy, dzięks występują inne elementy językowe. Są to przede wszystkim:

1) elementy wskazujące na fakt, że wypowiedź antycypująca podziękowanie jest również podziękowaniem (np. element ja również w wypowiedzi ja również dziękuję //, czy element to my w wypowiedzi to my dziękujemy //);

2) czasowniki performatywne, inne niż czasownik dziękować (np. czasownik zapraszamy w wypowiedzi bardzo dziękujemy / zapraszamy $w$ bieszczady //);

3) element bądź elementy oznaczone symbolem „[-]”, wskazującym na obecność w wypowiedzi niezrozumiałego dla transkrybenta fragmentu;

4) leksemy obcojęzyczne za wyjątkiem rozpowszechnionego w języku polskim wykrzyknienia wow (np. leksem thanks w wypowiedzi dziękuję / thanks //).

Decyzję ograniczenia się do ww. form samodzielnych uzasadniona jest koniecznością jednoznacznego stwierdzenia, że wyszczególnione wypowiedzi reaktywne są podziękowaniem (nie stanowią realizacji tzw. gatunku mieszanego). W materiale źródłowym nie identyfikuje się ponadto wypowiedzi zbudowanych $\mathrm{z}$ samodzielnych formuł dziękuję, dzięki, dziękujemy, dzięks, które nie są poprzedzone bezpośrednio z nimi powiązaną wypowiedzią inicjatywną oraz wypowiedzi, które poprzedzone są

8 Zapis przykładów oraz wypowiedzi zaczerpniętych z materiału źródłowego wzorowany na: (Wyrwas 2002: 12) - z wyłączeniem podziału na pauzy krótkie i długie. Transkrypcja bez znaków interpunkcyjnych oraz wersalików. 


\section{Anna Wartecka: Identyfikacja gatunku mowy pochwaty w oparciu o strategię reaktywnego gatunku mowy (SRGM)}

wypowiedzią inicjatywną przyjmującą postać tzw. makrowypowiedzi typu 1., makrowypowiedzi typu 2., poliwypowiedzi lub wypowiedzi domyślnej. 9

W rezultacie przeprowadzenia 4. etapu SRGM wyszczególniono z materiału źródłowego 648 wypowiedzi inicjalne (tzw. „korpus potencjalnych pochwał”) oraz tyle samo replik w postaci podziękowań.

\section{V.SRGM - ETAP V}

Ostatnim etapem SRGM na drodze do wyłonienia korpusu pochwał jest identyfikacja w korpusie potencjalnych pochwał tych wypowiedzi, które są inicjatywne względem gatunku podziękowania, lecz nie mogą zostać uznane za pochwałę, a następnie usunięcie ich $\mathrm{z}$ otrzymanego $\mathrm{w}$ rezultacie przeprowadzenia 4. etapu SRGM zbioru 648 wypowiedzi inicjatywnych. Etap ten rozpoczyna się od usunięcia $\mathrm{z}$ korpusu potencjalnych pochwał tych wypowiedzi, które zawierają element niezrozumiały dla transkrybenta (oznaczany za pomocą symbolu ,[-]”) oraz tych wypowiedzi, które zawierają leksem wypowiedziany w języku obcym ${ }^{10}$ (łączna liczba usuniętych według tych kryteriów wypowiedzi wynosi: 36). Powyższe wypowiedzi nie mogą zostać uznane za pochwały, albowiem 1) w przypadku występowania w wypowiedzi elementu niezrozumiałego dla transkrybenta - element ten jest nieznany i może potencjalnie przyjmować postać komponentu charakterystycznego dla innego niż pochwała, inicjatywnego względem podziękowania, gatunku mowy; 2) w przypadku występowania w wypowiedzi leksemu obcojęzycznego analiza genologiczna wypowiedzi (a tym samym stwierdzenie ich gatunkowości) staje się niemożliwa (za warunek jej przeprowadzenia uznaje się dla niniejszego badania realizację wypowiedzi w całości w języku polskim). Kolejnym krokiem jest identyfikacja tych wypowiedzi, które posiadają w swojej strukturze językowej komponent charakterystyczny dla innego niż pochwała, inicjatywnego względem podziękowania, gatunku mowy oraz usunięcia ich z pozostałego zbioru 612 wypowiedzi.

Możliwą obecność w strukturze językowej wypowiedzi wchodzących w skład potencjalnego korpusu pochwał elementów charakterystycznych dla innego niż pochwała, inicjatywnego względem podziękowania, gatunku mowy należy założyć, albowiem gatunek podziękowania jest reaktywny nie tylko wobec gatunku pochwały'11, lecz może być również reakcją na: aprobatę rozumianą jako zgodę/przyzwolenie (Marcjanik 2000: 198-199), gratulacje (Marcjanik 2000: 76), (inicjatywne) podziękowanie (Marcjanik 2000: 211),

9 Eksplikacji pojęć makrowypowiedzi typu 1., makrowypowiedzi typu 2., poliwypowiedzi oraz wypowiedzi domyślnej poświęcona jest część dysertacji doktorskiej (w przygotowaniu). Makrowypowiedzi typu 1., makrowypowiedzi typu 2. oraz poliwypowiedzi nie są brane pod uwagę w niniejszym badaniu, ponieważ nie spełniają jednej z podstawowych cech wypowiedzi w ujęciu Michała Bachtina, jakim jest posiadanie przez wypowiedź granic, którą nakreśla zmiana podmiotów mowy (Bachtin 1986: 363). Z badania wyłączone są również wypowiedzi domyślne, których zrozumienie [a tym samym przyjęcie postawy tzw. współodpowiadającego rozumienia (Bachtin 1986: 360)] możliwe jest jedynie w przypadku znajomości bezpośrednio antycypujących je (i komplementarnych względem nich) wypowiedzi. 10 Za wyjątkiem leksemu wow oraz zapożyczeń (często spolszczonych), których użycie umotywowane jest nadaniem wypowiedzi charakteru slangu młodzieżowego (celem nie jest w tym przypadku komunikacja z uczestnikiem-obcokrajowcem).

11 Do pochwały zalicza się w niniejszym badaniu również komplement. 
życzenie (Sikora 2013: 184 i Marcjanik 2000: 71), obietnicę (Marcjanik 2000: 197), radę (Marcjanik 2000: 198), informację ${ }^{12}$ (Marcjanik 2000: 193-196), pocieszenie (Marcjanik 2000: 199), deklarację pomocy (Marcjanik 2000: 115), kondolencje (Marcjanik 2000: 79), zaproszenie/propozycję (Marcjanik 2000: 109,198), poczęstunek (Marcjanik 2000: 95), (indywidualnie adresowany) toast (Marcjanik 2000: 155).13 Występowanie wśród wypowiedzi potencjalnych pochwał elementów charakterystycznych dla któregokolwiek z ww. gatunków mowy pozwala na wysunięcie przypuszczenia, że dana wypowiedź, w której element ten występuje jest realizacją gatunku mowy, dla którego element ten jest właściwy lub też - jest realizacją mieszanego gatunku mowy [a zatem nie może zostać uznana za realizację (wyłącznie) gatunku mowy pochwały].

Identyfikację elementów charakterystycznych dla innego niż podziękowanie, inicjatywnego względem gatunku podziękowania gatunku mowy (oraz usunięcie z korpusu potencjalnych pochwal tych wypowiedzi, które element ten zawierają) należy rozpocząć od poszukiwania elementów charakterystycznych dla tych gatunków mowy inicjatywnych względem gatunku podziękowania, których wystąpienie $\mathrm{w}$ korpusie potencjalnych pochwał jest oczekiwane (tzn. dana sytuacja komunikacyjna sprzyja ich wystąpieniu). Można założyć, że będą to te gatunki mowy, które wykazują tendencję do krzyżowania się z gatunkiem mowy pochwały, tj. podziękowanie i gratulacje (Drabik 2004: 61), a także spokrewnione w drugiej linii $\mathrm{z}$ pochwałą (za pośrednictwem gratulacji) - życzenia. Za gatunek mowy, którego wystąpienie w korpusie potencjalnych pochwał jest oczekiwane należy uznać także aprobatę (rozumianą tu jako przyzwolenie na promocję uczestnika do następnego etapu konkursu). Zasadność założenia wystąpienia aprobaty w korpusie potencjalnych pochwał uzasadniona jest przez dwa czynniki: 1) pokrewieństwo pochwały i aprobaty, o którym świadczy m.in. obecność pojęcia „Pochwała” w polu semantycznym pojęcia „Aprobata” 14 oraz 2) istotę danej sytuacji komunikacyjnej [celem uczestników biorących udział w rundzie eliminacyjnej programu „Mam talent!” jest zaprezentowanie swoich umiejętności, w cel ten zaś wpisuje się (niejako automatycznie) nadzieja na otrzymanie przez uczestnika pozytywnej oceny ze strony jurorów, a w konsekwencji - na promocję do dalszych etapów konkursu'15, która dokonuje się w akcie wyrażenia przyzwolenia (aprobaty)]. Po identyfikacji

\footnotetext{
12 Chodzi tu o następujące rodzaje informacji (zwane dalej zbiorczo „informacją”): 1) informację o wręczaniu podarunku; 2) zapowiedź wręczenia podarunku; 3) informację o wypełnianiu/wypełnieniu przysługi (uprzejmości) lub prośby, a także potwierdzenie realizacji tego działania; 4) przekazanie ważnej dla adresata wiadomości; 5) informację o zrobieniu czegoś dla adresata, co osoba dziękująca ocenia jako wykraczające poza obowiązkowe czynności; 6) zapowiedź spełnienia prośby (Marcjanik 200o: 193-197).

$13 \mathrm{~W}$ artykule wymieniono te najpopularniejsze w języku polskim gatunki mowy, po których wystąpienie reaktywnego gatunku mowy podziękowania uznawane jest za typowe.

14 Hasło „aprobata” w Uniwersalnym Słowniku Języka Polskiego pod red. Stanisława Dubisza [www.usjp.pwn.pl (dostęp w dniu 02.05.2017)].

15 Możliwość dalszego występowania w programie jest więc oczekiwanym przez uczestnika dobrem i korzyścią. Ponieważ bodziec podziękowania określany jest m.in. jako „zrobienie czegoś, co jest dla nadawcy podziękowania dobre” (Marcjanik 200o: 192 za Wierzbicka 1973: 214), a także m.in. jako „coś, co przynosi nadawcy podziękowania korzyść” (Marcjanik 2000: 192 za Norrick 1978: 285) konsekwentnie uznaje się inicjatywność aprobaty (rozumianej tu jako przyzwolenie na uczestnictwo konkursanta w dalszych etapach programu) względem gatunku mowy podziękowania.
} 
Anna Wartecka: Identyfikacja gatunku mowy pochwaty $w$ oparciu o strategię reaktywnego gatunku mowy (SRGM)

i usunięciu z korpusu potencjalnych pochwał tych wyżej opisanych wypowiedzi, których wystąpienie w danym korpusie jest oczekiwane (są to, kolejno, wypowiedzi zawierające element językowy charakterystyczny dla następujących gatunków mowy: aprobaty, gratulacji, podziękowań oraz życzeń) ${ }^{16}$ dokonuje się przeglądu pozostałych wypowiedzi pod kątem wystąpienia w nich językowych „markerów” innych, wyżej wymienionych, reaktywnych względem gatunku podziękowania gatunków mowy, tj. obietnica, pocieszenie, informacja, rada, deklaracja pomocy, kondolencje, zaproszenie/propozycja, poczęstunek, (indywidualnie adresowany) toast (a następnie usunięcia wypowiedzi zawierających ww. „marker” z korpusu potencjalnych pochwał). Opis elementów językowych służących do identyfikacji wszystkich ww. gatunków mowy oraz przedstawienie procedury ich identyfikacji następuje w poniższej części artykułu (V.1.-V.5.)

\section{Identyfikacja i eliminacja z korpusu potencjalnych pochwał wypowiedzi zawierających językowy element charakterystyczny dla gatunku mowy APROBATY}

Za element językowy charakterystyczny dla gatunku mowy aprobaty (rozumianej tu jako zgodę/przyzwolenie na promocję uczestnika do następnego etapu konkursu) uznaje się:

$>$ partykułę twierdzącą tak;

$>$ wyrażenie jestem za;

$>\quad$ wyrażenie przechodzisz (do następnego/kolejnego etapu);

> wyrażenie zapraszamy (do nastęnego/kolejnego etapu);

$>$ leksem witaj [leksem witaj (a także bliski semantycznie leksem witamy) współwystępuje $\mathrm{w}$ niektórych wypowiedziach $\mathrm{z}$ partykułą twierdzącą tak i może być traktowany jako symboliczne powitanie uczestnika w kolejnej rundzie programu (stanowiąc tym samym domyślną zgodę na promocję uczestnika do następnego etapu konkursu)]. ${ }^{17}$

Przykłady wypowiedzi wyeliminowanych z korpusu potencjalnych pochwał, które zawierają jeden lub kilka ww. elementów uznanych za charakterystyczne dla gatunku mowy aprobaty są następujące: trzy razy tak //[MT!I2(oo:13:10)J1X] ${ }^{18}$; panowie / zostatem przeglosowany / no trudno

\footnotetext{
16 Procedura rozpoczyna się od identyfikacji i usunięcia tych wypowiedzi, które zawierają wyżej opisany element językowy uznany (szacunkowo) za najliczniej występujący w korpusie potencjalnych pochwał. Identyfikacja w wypowiedzi językowego „markera” aprobaty jest równoznaczna z usunięciem wypowiedzi z korpusu (wypowiedzi takiej nie poddaje się kolejnej analizie pod kątem występowania w niej elementu językowego charakterystycznego dla gratulacji, podziękowań itd. itp.).

17 Elementy te stanowią komponent (niekiedy wyłączny) tych wypowiedzi, które padają w czasie przeznaczonym na głosowanie, co do przyszłych losów uczestnika w programie (co uzasadnia ich wybór jako „markerów” gatunku mowy aprobaty omawianej w niniejszym artykule).

18 Wypowiedzi opatrzone są sygnaturą, w której: symbol „MT!” jest skrótowcem utworzonym od nazwy programu; symbol typu „I2” oznacza numer edycji oraz odcinka; symbol typu „(oo:13:10)” oznacza orientacyjny czas wypowiedzi (będący czasem pierwszego komentarza po danym występie uczestnika); symbol typu „J1X” jest oznaczeniem nadawcy wypowiedzi.
} 
/ zawsze bylem odrębny / jestem za // [MT!I1(01:13:08)J1X]; U przechodzisz // [MT!I1(Oo:32:11)J1X]; zapraszamy // [MT!VI3(oo:50:49)J1]; nie ma o czym mówić / U / oczywiście witaj // [MT!IV3(01:06:08)J3].

Liczba wyeliminowanych wypowiedzi zawierających element charakterystyczny dla gatunku mowy aprobaty wynosi: 241 (w korpusie potencjalnych pochwał pozostaje 371 wypowiedzi).

\section{Identyfikacja i eliminacja z korpusu potencjalnych pochwal wypowiedzi zawierających językowy element charakterystyczny dla gatunku mowy GRATULACJI}

Za element językowy charakterystyczny dla gatunku mowy gratulacji uznaje się czasownik performatywny typu ${ }^{19}$ gratulować oraz wyrażenie perfomatywne składać gratulacje20 (Marcjanik 2000: 74). Rozpoznanie wypowiedzi w korpusie potencjalnych pochwał, które zawierają element charakterystyczny dla gatunku mowy gratulacji dokonuje się poprzez identyfikację w nich:

$>$ leksemu gratulować w performatywnej formie gramatycznej gratuluje;

$>$ leksemu gratulować w performatywnej formie gramatycznej gratulujemy;

$>$ leksemu gratulować w performatywnej formie gramatycznej gratulować (w użyciu typu: muszę ci pogratulować //21);

$>$ leksemu gratulować $\mathrm{w}$ innych performatywnych formach gramatycznych (np. w formie imiesłowu gratulując w wypowiedzi gratulując / chcę ci powiedzieć że jesteś świetny //);

$>$ leksemu gratulacje, będącego częścią wyrażenia performatywnego sktadać gratulacje (czasownik składać może być w tym przypadku domyślny).22

Przykłady wypowiedzi wyeliminowanych z korpusu potencjalnych

pochwal, które zawierają jeden lub kilka ww. elementów uznanych za charakterystyczne dla gatunku mowy gratulacji są następujące: to po prostu bylo fantastyczne / twój świat / twoja wrażliwość / absolutnie strzał w moje serce / jestem zachwycona / gratuluje / $z$ catego serca // [MT!IX2(o0:26:29)J1]; gratulujemy $z$ catego serca // [MT!IX6(01:06:05)J1]; $U$ / no coś niesamowitego / ja muszę ci powiedzieć że / ja muszę ci powiedzieć że przychodza tu różne dziewczyny / śpiewaja lepiej / gorzej / najgorsze sq te które przychodzq z tak zwanym pawim piórkiem w tytku / wiesz / a to co w tobie jest niesamowitego / to jest to że

19 Za typ czasownika performatywnego gratulować uznaje się w niniejszym badaniu także czasownik winszować oznaczający m.in. „składać komuś gratulacje” (Słownik Języka Polskiego PWN, hasło: „winszować”, www.sjp.pwn.pl, dostęp w dniu 29.03.2018).

20 Również: składać powinszowania.

21 Wszystkie wymienione w powyższym punkcie elementy językowe pochodne od leksemu gratulować mogą występować z przedrostkami. 22 Analogicznie do leksemów gratulować/gratulacje rozpoznaniu poddaje się leksemy winszować/powinszowania. 
Anna Wartecka: Identyfikacja gatunku mowy pochwaty $w$ oparciu o strategię reaktywnego gatunku mowy (SRGM)

przyszłaś taka skromna / taka absolutnie niepozorna / i po prostu zrobiłaś coś takiego / żeja mogę tylko ci gratulować / i głosu / talentu / fantastyczny występ / naprawdę // [MT!III3(Oo:53:31)J1]; gratulacje // [MT!VII6(oo:19:53)J1].

Liczba wyeliminowanych wypowiedzi zawierających element charakterystyczny dla gatunku mowy gratulacji wynosi: 23 (w korpusie potencjalnych pochwał pozostaje 348 wypowiedzi).

\section{Identyfikacja i eliminacja z korpusu potencjalnych pochwał wypowiedzi zawierających językowy element charakterystyczny dla gatunku mowy PODZIĘKOWANIA}

Za element językowy charakterystyczny dla gatunku mowy podziękowania uznaje się (na danym etapie analizy) czasownik performatywny dziękować (Marcjanik 2000: 192), wykrzykniki dzięki oraz dzięks (Cyluk 2012: 17-18), wyrażenie performatywne typu składam podziękowania/składam wyrazy wdzięczności, wyrażenia typu jestem wdzięczny (Marcjanik 2000: 193) oraz inne (synonimiczne do jestem wdzięczny) wyrażenia zawierające leksem wdzięczność. Rozpoznanie wypowiedzi w korpusie potencjalnych pochwał, które zawierają element charakterystyczny dla gatunku mowy podziękowania dokonuje się poprzez identyfikację w nich:

$>$ leksemu dziękować w performatywnej formie gramatycznej dziękuję;

$>$ leksemu dziękować w performatywnej formie gramatycznej dziękujemy;

$>$ leksemu dziękować w performatywnej formie gramatycznej dziękować (w użyciu typu: muszę ci podziękować //23);

$>$ leksemu dziękować w innych performatywnych formach gramatycznych (np. w formie imiesłowu dziękując w wypowiedzi dziękując / chcę ci powiedzieć że jesteś świetny //);

$>$ wykrzynika dzięki;

$>$ wykrzyknika dzięks;

$>$ leksemu podziękowania (w formach gramatycznych podziękowanie/podziękowania), będącego częścią składową wyrażenia performatywnego składać podziękowania (czasownik składać może być w tym przypadku domyślny) oraz wyrażeń typu proszę przyjąć podziękowania;

$>$ leksemu wdzięczny (w dowolnej formie gramatycznej) jako części składowej wyrażenia typu jestem wdzięczny;

$>$ leksemu wdzięczność (w dowolnej formie gramatycznej) jako części składowej wyrażenia synonimicznego do wyrażenia jestem wdzięczny (np. jako części składowej wyrażenia moja wdzięczność nie ma 
granic //).

Przykłady wypowiedzi wyeliminowanych z korpusu potencjalnych pochwał, które zawierają jeden lub kilka ww. elementów uznanych za charakterystyczne dla gatunku mowy podziękowania są następujące: piękno ludzkiego ciała pokazane $w$ sposób niezwykle subtelny / przepiękny / bardzo wam dziękuję za to // [MT!I1(0o:37:45)J3]; brawo / dziękujemy // [MT!I2(oo:18:55)J1]; chcemy ci bardzo podziękować po prostu za to / że zechciałaś do nas przyjść // [MT!VIII4(00:57:00)J1]; dzięki ci / imienia nie powtórzę / to powiem / dzięki ci stary // [MT!V6(00:25:00)J1].

Liczba wyeliminowanych wypowiedzi zawierających element charakterystyczny dla gatunku mowy podziękowania wynosi: 47 (w korpusie potencjalnych pochwał pozostaje 301 wypowiedzi).

\section{Identyfikacja i eliminacja z korpusu potencjalnych pochwał wypowiedzi zawierających językowy element charakterystyczny dla gatunku mowy ŻYCZEŃ}

Za element językowy charakterystyczny dla gatunku mowy życzeń uznaje się czasownik performatywny życzyćc ${ }^{4}$ oraz wyrażenie perfomatywne składać życzenia (Marcjanik 2000: 63-72). ${ }^{25}$ Rozpoznanie wypowiedzi w korpusie potencjalnych pochwał, które zawierają element charakterystyczny dla gatunku mowy życzeń dokonuje się poprzez identyfikację w nich:

$>$ leksemu życzyć w performatywnej formie gramatycznej życzę;

$>$ leksemu życzyć w performatywnej formie gramatycznej życzymy;

$>$ leksemu życzyć w performatywnej formie gramatycznej życzyć (w użyciu typu: chciałabym ci życzyć //);

$>$ leksemu życzyć w innych perfomatywnych formach gramatycznych (np. w formie imiesłowu życząc w wypowiedzi życząc ci wszystkiego dobrego / chcę ci powiedzieć że jesteś świetny //);

$>$ leksemu życzenia, będącego częścią wyrażenia performatywnego składać życzenia (czasownik składać może być w tym przypadku domyślny). ${ }^{26}$

Leksemy życzyć/życzenia występujące ww. postaciach mogą być domyślne [na ich obecność w postaci implicite w wypowiedzi wskazuje (obecna explicite $\mathrm{w}$ wypowiedzi) fraza nominalna oznaczającą przedmiot życzenia (w dopełniaczu), np. wszystkiego dobrego, powodzenia].

Przykłady wypowiedzi wyeliminowanych z korpusu potencjalnych pochwał, które zawierają jeden lub kilka ww. elementów uznanych za charakterystyczne dla gatunku mowy życzeń są następujące: super / jesteś po prostu doskonaty / $i$ zrób wszystko z tym co chcesz / naprawdę /

24 Za wyjątkiem sytuacji, w której czasownik ten wchodzi w skład wyrażenia życzyć sobie.

25 A także: 1) używany w formach performatywnych leksem winszować (Sikora 2013: 179), oznaczający m.in. „składać komuś gratulacje” (Słownik Języka Polskiego PWN, hasło: winszować, www.sjp.pwn.pl, dostęp w dniu 29.03.2018) oraz 2) (analogicznie do wyrażenia performatywnego składać życzenia) wyrażenie performatywne: składać powinszowania).

26 Analogicznie do leksemów gratulować/gratulacje rozpoznaniu poddaje się leksemy winszować/powinszowania. 
Anna Wartecka: Identyfikacja gatunku mowy pochwaty w oparciu o strategię reaktywnego gatunku mowy (SRGM)

powodzenia // [MT!III3(01:03:46)J1]; życze ci z całego serca nie tyle kariery / wiesz / tylko żebyś pięknie śpiewała / jak najdłużej / jak najdłużej / $U$ // [MT!V6(01:06:20)J1]; wszystkiego dobrego // [MT!IX4(00:42:00)J3].

Liczba wyeliminowanych wypowiedzi zawierających element charakterystyczny dla gatunku mowy życzeń wynosi: 6 (w korpusie potencjalnych pochwał pozostaje 295 wypowiedzi).

\section{Identyfikacja i eliminacja $z$ korpusu potencjalnych pochwał wypowiedzi zawierajacych językowy element charakterystyczny dla (wyżej wymienionych) POZOSTAŁYCH ${ }^{27}$ GATUNKÓW MOWY}

Za element językowy charakterystyczny dla gatunku mowy:

1) OBIETNICY - uznaje się leksem obiecywać oraz wyrażenie składać obietnicę;28

2) RADY - uznaje się leksemy radzić/odradzać;

3) KONDOLENCJI - uznaje się leksem wspótczuć, frazę nominalną wyrazy wspótczucia oraz leksem kondolencje;

4) ZAPROSZENIA/PROPOZYCJI - uznaje się (odpowiednio): leksemy zapraszać/zaproszenie oraz proponować/propozycja;

5) POCZĘSTUNKU - uznaje się najpopularniejsze struktury językowe wyszczególnione przez M. Marcjanik (Marcjanik 2000: 82-94);

6) TOASTU (INDYWIDUALNIE ADRESOWANEGO) - uznaje się (użyty w charakterze wykrzyknika) leksem zdrowie (Marcjanik 2000: 146-148, 155);

7) INFORMACJI - uznaje się stałe wyrażenie proszę (Marcjanik 2000: 196);

8) DEKLARACJI POMOCY - uznaje się struktury językowe wyszczególnione przez M. Marcjanik (Marcjanik 2000: 114).

W korpusie potencjalnych pochwał wyróżnia się (w oparciu o ww. kryteria), a następnie eliminuje 1 wypowiedź informacji, tj. proszę bardzo // [MT!VIII6(oo:45:57)J1] oraz 1 wypowiedź deklaracji pomocy, tj. zaopiekujemy się toba // [MT!VI5(00:30:31)J2]. W korpusie potencjalnych pochwał pozostają 293 wypowiedzi.

27 W niniejszym badaniu nie wyszczególnia się elementów językowych charakterystycznych gatunku mowy POCIESZENIA [gatunek ten uznaje się (za: Drabik 2010: 197) za niejednorodny pod względem swojej formy (pozbawiony czasownika performatywnego i wysoko skonwencjonalizowanych form)]

28 We wszystkich użyciach i formach o charakterze performatywnym (dotyczy leksemów i fraz nominalnych wymienionych we wszystkich ww. punktach). 


\section{ZAKOŃCZENIE}

Pozostałe w korpusie potencjalnych pochwał wypowiedzi uznaje się za pochwały (zostaną one poddane dalszej analizie leksykalno-gramatycznej). W wyniku przeprowadzonej SRGM zmniejszono ryzyko wystąpienia w korpusie potencjalnych pochwał innych, inicjatywnych względem gatunku podziękowania, gatunków mowy, choć ryzyka tego nie wyeliminowano całkowicie. Związane jest ono z następującymi czynnikami: 1) możliwością wystąpienia $\mathrm{w}$ ww. korpusie gatunków innych, niż typowe inicjatywne względem podziękowania gatunki mowy; 2) możliwością wystąpienia w ww. korpusie wypowiedzi noszących mniej popularne znamiona gatunków mowy inicjatywnych względem podziękowania; 3) możliwością wystąpienia w ww. korpusie gatunków zamaskowanych, dla właściwego rozpoznania których nie wystarczy znajomość płaszczyzny językowej wypowiedzi, ale konieczna jest znajomość intencji nadawcy [przykładem może tu być dziękowanie przy pomocy komplementu (Drabik 2004: 61-62)]. Ryzyko to uznaje się za nieznaczące dla dalszego badania pozostałych wypowiedzi. 


\section{Anna Wartecka: Identyfikacja gatunku mowy pochwaty $w$ oparciu o strategię reaktywnego gatunku mowy (SRGM)}

\section{Bibliografia}

Bachtin, M. 1986. Estetyka twórczości stownej. Warszawa: P.I.W.

Cyluk, A. 2012. Akty podziękowań i ich repliki w mówionej polszczyźnie - studium oparte na korpusie. w: Szymula R. (red.) Linguodidactica, t. XVI. Białystok: Wydawnictwo Uniwersytetu w Białymstoku. pp. 15-30.

Drabik, B. 2004. Komplement $i$ komplementowanie jako akt mowy $i$ komunikacyjna strategia. Kraków: Universitas.

Drabik, B. 2010. Językowe rytuaty tworzenia więzi interpersonalnej. Kraków: WUJ.

Marcjanik, M. 2000. Polska grzeczność językowa. Kielce: WAŚ.

Norrick, N. R. 1978. Expressive Illocutionary Acts. w: Journal of Pragmatics, nr 2. pp. 277-291.

Sikora, K. 2013. Życzenia i winszowanie jako akty mowy. w: Skarżyński, M. (red.): LingVaria, nr 2(13). Kraków: Księgarnia Akademicka. pp 179-189.

Wierzbicka, A. 1973. Akty mowy. w: Mayenowa, M. R. (red.) Semiotyka i struktura tekstu. Wrocław: ZN im. Ossolińskich. pp. 201-219.

Wyrwas, K. 2002. Skarga jako gatunek mowy. Katowice: WUŚ.

Stownik języka polskiego PWN. URL: http://sjp.pwn.pl/

Uniwersalny Stownik Języka Polskiego. Dubisz, S. (red.). URL: http://usjp.pwn.pl/ 